\title{
ONLINE MEDIA AND ESTABLISHMENT OF RELIGIOUS UNDERSTANDING OF THE MADRASAH ALIYAH STUDENTS IN GORONTALO
}

\author{
Sitti Arafah', Basman Basman'2, Khaerun Nisa'3, Asnandar Abubakar'4 \\ 1,3,4 Office of Religious Research and Development Makassar, Ministry of Religious Affairs \\ ${ }^{2}$ Sultan Amai State Islamic Institute, Gorontalo \\ 1sittiarafah0702@gmail.com, 2drbasman@gmail.com,3khaerun.nisa@kemenag.go.id, \\ 4asnandar2.aja@gmail.com
}

\begin{abstract}
This research is a qualitative descriptive study that aims to describe the religious understanding of Madrasah Aliyah (MA) students in Gorontalo obtained from online media. It was also conducted to determine the school's response in harmonizing religious understanding. This study aims to answer the following questions: (1) How is the religious understanding of Madrasah Aliyah students obtained through online media? and (2) How do the schools respond and harmonize the religious understanding of students who interact with online religious sites? Data were collected through observation, interviews, and documents study, by targeting Madrasah Aliyah students, teachers, religious leaders, academics, and community leaders. The results showed that MA students use online media as sources of learning materials and religious content with the duration of accessing online media reaching 4 to 10 hours per day. It has influenced the understanding, attitudes, and religious practices of MA students. The understanding and practice of "exclusive" religion have become widespread, among students no longer celebrating the Prophet's birthday (mawlid), barzanji, tahlil, prohibiting to wish someone Merry Christmas, forbidding music, forbidding to take self pictures, and considering the traditions of the Gorontalo people which aren't following Islamic values as heretical and forbidden. As a response to dealing with the problems above, the school tries to align students' religious understanding by strengthening religious moderation for teachers and students, building communication with students in social media, and providing mentors for students. This study recommends: (1) the importance of strengthening the understanding of religious moderation to teachers and students, (2) encourage religious institutions such as $\mathrm{NU}$ and Muhammadiyah to use online media as a da'wah tool, and use language that easy to understand by the millennial generation.
\end{abstract}

Keywords: Online media; madrasah aliyah students; religious understanding.

Abstrak: Penelitian ini merupakan penelitian kualitatif-deskriptif untuk mendeskripsikan pemahaman dan praktik keagamaan pada siswa Madrasah Aliyah (MA) di Kota Gorontalo yang diperoleh melalui media online. Di samping, untuk mengetahui respon sekolah dalam menyelaraskan paham keagamaan tersebut. Adapun pertanyaan penelitian: (1) bagaimana wacara keagamaan siswa Madrasah Aliyah yang diterima melalui media online? dan (2) bagaimana pihak sekolah merespon dan menyamenyelaraskan pemahamn siswa yang berinterkasi dengan situs keagamaan media online? Penjaringan data dan informasi dengan menggunakan tehnik pengumpulan data melalui observasi, wawancara dan dokumen, dengan menyasar siswa Madrasah Aliyah, para guru, tokoh agama, akademisi, maupun tokoh masyarakat. Hasil penelitian menunjukkan bahwa media online telah menjadi kebutuhan siswa, selain dimanfaatkan untuk pembelajaran juga digunakan dalam mengakses konten keagamaan. Intensitas waktu yang digunakan antara 4 sampai 
10 jam/hari, melalui aplikasi Face Book, Whaatshap, Instagram, Google, Twitter, laman/situs maupun chanel youtube. Media online memiliki pengaruh, baik pada pemahaman, sikap maupun praktik keagamaan siswa Madrsah Aliyah. Pemahaman dan praktik kegamaan "ekslusive", telah mengejala, di antara siswa tidak lagi melakukan seperti, mawlid nabi, barzanji, tahlilan, mengucapkan selamat natal, mengharamkan music, dan berfoto, serta tradisi masyarakat Gorontalo yang tidak sesuai dengan nilai-nilai Islam dianggap bid'ah dan haram. Adapun Penyelarasan oleh pihak sekolah, antra lain: penguatan moderasi beragama bagi guru maupun siswa, membangun komunikasi dengan siswa dalam bermedia sosial, pendampingan kepada siswa. Penelitian ini merekomendasikan (1) pentingnya penguatan pemahaman moderasi beragama kepada guru dan siswa. (2) Lembaga keagamaan seperti NU dan Muhammadiyah merubah pola dakwah kearah penggunaan media online seperti youtube, serta menggunakan bahasa yang ringan dan mudah dipahami oleh kalangan generasi milleneal.

Kata kunci: Media online; siswa madrasah Aliyah; pemahaman agama

\section{A. Introduction}

New media (internet), as new invention of technological industry, became a popular media who able to surpass conventional media, both printed and visual media. Online media, as new media, has transformed into limitless space, where myriad information can be accessed easily, including in accessing religious content. Now humans live in a world of communication called hyper communication, which makes communication not only for some people with the media, but also between mass communicators and communicants. It's interesting that the media have not only become a cultural, political, and economic entity, but also led to ideology and even religion entities ${ }^{1}$. In this era, the media is no longer something foreign, and even, it has become the centre of communication, especially the internet, that popularly used by individuals. The new media (internet) that is currently booming provides easy access to communicate and present much information from anywhere in the world. Its presence has outperformed the conventional media such as radio and television. The existence of this new media has indeed changed the world of communication. Gabrielle Angraini stated that currently, in Indonesia, the dominant users of the internet are among the millennial generation ${ }^{2}$. The industrial era made it easy for everyone to access information through online media, even without considering the positive and the negative impacts.

Research conducted by the Indonesian Internet Service Providers Association (APJII) in 2018 stated that there were 171.17 million internet users in Indonesia, involving 5,900 samples, $71.8 \%$ of them are recognized as students. The majority of internet users are between 15-19 years, reaching $91 \%$ of the total users ${ }^{3}$.

The abundance of data sources, cheap and easy access to information, are the factors that make students enjoy interacting with the virtual world. Consumption of a variety of religious sites will, of course, form different understandings of religious aspects. It can have both negative and positive impacts on students. If students consume sites that teach religion moderately, then the student will build reasoning on moderate religious thought as well. The concern is if students intensively consume descriptive and closed religious understandings, it may encourage students to form close and exclusive generations, which aren't compatible with the survival of the nation and state.

\footnotetext{
${ }^{1}$ Haqqi Annazilli, “Relasi Antara Agama Dan Media Baru,” Jurnal Ilmiah Syi'ar 18, no. 2 (2018): 26-28.

2 Hatta. Muhammad, "Media Sosial Sebagai Sumber Keberagamaan Alternatif Remaja Dalam Fenomena Cyberreligion," Dakwah 22, no. 1 (2018): 1

3 Paisal, Media Online dan Pembentukan Pemahaman Keagamaan Siswa di MA pada Kawasan Timur Indonesia (Makassar, 2020), 1-2.
} 
This research will look at how online media has shaped students' discourse and practice, especially in Madrasah Aliyah. Therefore, this research will focus on two problems: (1) how the understanding and religious practices of MA students that are obtained through online media, and (2) how the teachers harmonize the understanding of student's understandings that obtained through online media. The aim is to conceive the understanding and practices of students who have accessed online media and read how the schools harmonize the understanding and practice that are received by students through online media.

\section{B. Theoretical Review}

Old media and new media. McQuail explains their different characteristics; old media is the concept of an object talking to audiences, while new media is more decentralized. Old media is a one-way communication, while new media allows feedback from the audience. Old media is under state control, while new media is commonly spreading without state boundaries ${ }^{4}$. The mass media (print and online) is a very effective mediator for publication and ideological formation. The form and practice of ideology, writing, language, and grammatical coherence are parts of the text that have certain meanings and can be chosen to gain public supports ${ }^{5}$.

Decoding and Encoding: by Stuart Hall, is a way of explaining that the same message can be sent and interpreted in not only one way. This method focuses on the idea that audiences often translate media messages in ways that don't match the source of the message could lead to different meanings. A message that is sent or delivered will affect the audience. Stuart Hall identified three categories of audiences that have undergone the process of encoding/decoding a message. ${ }^{6}$

"The Revolutionary Parenting", a work by Goerge Barna describes in detail the spiritual experiences conveyed through the internet, where "seekers of God" in America take advantage of the internet, so this may pose a threat to church institutions so that churches will experience a significant decline in the congregation. Furthermore, Garry R. Bunt, saw how Islamic preaching was very passionate about using the internet as a medium of preaching. Bunt concluded that Islam is able to become familiar with CMC (Computer Mediated Communication). Meanwhile, E. Brashar believes that spiritual value doesn't see it from religions but can thrive in cyberspace?

\section{Methods}

This research uses qualitative research to collect and extract data. Researchers did observation as a method to directly observe the schools as objects of this study, MAN Gorontalo, MA Al-Yusrah, MA Al-Khaerat, and MA Al Hudah Gorontalo ${ }^{8}$. Furthermore, the purposive interviews were conducted with several informants include students, teachers, academics, and practitioners. ${ }^{9}$ The documents study/review intends to collect written data and information. The data that has been collected both in observation and interviews were then further analysed descriptively and qualitatively.

\footnotetext{
${ }^{4}$ McQuail. Dennis, Teori Komunikasi Massa Mc.Quail, Enam (Jakarta: Salemba Humanika, 2011), 4.

5 Eriyanto, Analisis Wacana Pengantar Analisis Teks Media, Pertama (Jogyakarta: LKiS, 2005), 15.

6 Zohrah. Fatimah, "Pemaksanaan Khalayak terhadap Informasi Kasus Penodaan Agama Oleh Basuki Tjahja Purnama di Media Sosial” (Universitas Diponegoro Semarang, 2017), 4-5.

7 Hatta. Muhammad, "Media Sosial sebagai Sumber Keberagamaan Alternatif Remaja dalam Fenomena Cyberreligion."8-9.

8 Ahmadin, Metode Penelitian Sosial, Pertama. (Jakarta: Rayhan Intermedia, 22013).99.

${ }_{9}^{9}$ Naniek Kasniyah, Tahapan Menentukan Informan dalam Penelitian Kualitatif (Yogyakarta: Ombak, 2012): 8-12.
} 


\section{Results and Discussions}

\section{Religious Understanding of Students in Madrasah Aliyah in Gorontalo}

Adolescence is not only a period of self-search and self-identity search, but it's also a period when teenagers are still in unstable conditions, where they need a strong fortress to prevent them falling into negative actions. Spiritual emptiness can create various problems both individually and socially. Religious knowledge is very important for every individual. Islamic education is considered one of the alternatives that can fortify every teenager to do merit, religious values should be embedded in them. Religion should be a bulwark from all that is bad. The era of technology is something that's unstoppable, but we are not able to carry away, religious education is expected to lead teenagers to find positive potential themselves. Effective spending time on social media can minimize the negative impact on the lives of teenagers so they still have many opportunities to study religion more deeply. ${ }^{10}$

The development of students' religious understanding in Gorontalo is currently undeniably dynamic and is shifting. Access to religious knowledge is quite open and they always feel a lack of religious knowledge. Madrasah Aliyah students with various religious studies are still trying to find various religious knowledge outside the school, including through online media.

Along with their activeness in seeking religious knowledge, it seems that online media has influenced their understanding, behavior, religious practices, and social relations. In social relations, students supposed to have a high tolerance attitude, respect and appreciate differences, greet and help each other. However, in practice, such as choosing leaders from different religions and saying Merry Christmas, none of them agreed and they in a unified manner stated that those are against the religious teaching of Islam.

The shifting of the student's religious understanding is certainly influenced by several indicators. Bids and information access today are quite diverse, especially in the religious sphere. Religious knowledge is available, packed with diverse interests of readers, presented very instantly, especially grain through online media. The presentation of religious knowledge obtained through online media is quite influential in the formation of their religious understanding. However, the religious content they found on the internet and among the students make them able to draw comparisons of what they get both through references and on religious discussions they follow outside the school.

\section{The Tendency of Madrasah Aliyah Students to Learn from the Internet}

Teens and social media are like two sides of a coin that cannot be separated. Social media makes teenagers master new things in life. It leads to the fact that social media is the real world, which is rapidly changing the patterns and behavior of teenagers' lives, the character of adolescents is still easily shaken so that online media can easily influence them. ${ }^{11}$ Research published by Crowdtap, IPSOS Media CT, and The Wall Street Journal, 2014 involving 839 respondents from the age of 16 to 36 years showed that the time spent by audiences to access the internet and social media reached up to 6 hours 46 minutes per day, exceeding the time of accessing traditional media. ${ }^{12}$

The current progress of media culture can affect various lines of social order, including religious life. Access to religious knowledge is more instant and practical. In order to be able to read the al-Qur'an and understand religion, it is no longer necessary to seek for the ustaz or

\footnotetext{
10 Saputra. Eddy, "Dampak Media Sosial terhadap Sikap Keberagamaan Remaja dan Solusinya Melalui Pendidikan Agama Islam," Sosial E-Kons 8, no. 2 (2016), 61.

11 Ibid.

12 Nurfitrih Aldila Dyas dan Mulawarman, "Perilaku Pengguna Media Sosial Beserta Implikasinya Ditinjau dari Perspektif Psikologi Sosial Terapan,” Buletin Psikologi 25, no. 1 (2017).37.
} 
cleric but simply by surfing through virtual world ${ }^{13}$. The freedom of information traffic via the internet allows Islamic religious knowledge to be found quickly.

Likewise, in Gorontalo, based on interviews conducted with several students, they spend between 4 to 10 hours / day on social media, while on holidays they can spend the whole day on social media. Mrs. Fitrih, (senior adviser of Rohis MAN 1 Gorontalo), said that at this time we can't turn a blind eye, that the tendency of children in the online media is about $75 \%$, they would feel something's missing if they don't their phones in a day. Including access to religious contents, of course this has to be one of the factors that influence the formation of their religious understanding. However, so far there has not been found any deviant or extreme religious understanding among the students, if any, it is only one or two people (casuistic) and school will immediately try to straighten them out.

It is undeniable that the religious understanding of madrasah aliyah students is also shaped by online media. In addition to religious reading materials and study activities outside of school, the phenomenon of "online recitation", or what is commonly known as cyber religion, is a recent phenomenon. As a result of the industrial revolution, which provides easy access to information across borders and space, including religious information that can be accessed instantaneously.

One of the media that is currently very popular is Youtube, which is also used as a medium for spreading Islamic da'wah, and it is considered as the most effective, can even be watched by many people, without limitation and it can be accessed by thousands that millions of people. This confirms that religion and online media have a significant relationship. Thus, it makes online media unique in forming relationships with religion, it will turn into a notable source for accessing religious contents, especially for the millennial generation ${ }^{14}$.

Nowadays, it seems that online media has played an important role in shifting individual and institutional religious power to the power of online media as a negative impact on the religious understanding that is gained instantly ${ }^{15}$. The use of online media for madrasah aliyah students is for accessing religious content. Religious sites/pages that they frequently accessed or visited including google, let's move, Islam today, Syubanul Muslim, Muslim.or.id, DakwahIslam.com, faedahsalaf.com, Islampost, Damai Indonesia, Muzammil Hasbaallah, Nuzuldzikri, Gorontalo Recitation, Abuazzamalumangi, Bandung Recitation, RojaTV, Jakarta recitation, Bogor recitation, and the another youtube channel of the preachers they love.

An interesting thing that also found in this study is the tendency of students towards ustaz they met on YouTube, including Ustas Abdul Somad, Ali Hidayat, Khalid Basalamah, Hannan Attaki, Zakir Naik, Firanda Andiria, Yazid bin Abdul. Qadir Jawaz, Syafiq bin Riza Basalamah, Ust. Baequnui, Taqi Malik, Ust Maulana, Oki Setiana Dewi, Umi Pipik, Ust. Muzammil Hasbaalah, Gus Azmi, Das'ad Latief, Toni Abas, Buya Yahya, ust. Khalid wali, ust. Yusuf Lauma, Lc, ust. Supardi, Habib Al-Habsy, Habib Umar, Habib Sadiq, Ust. Firanda, Gus Baha and Gus Miftah, Buya Yahya, Habib Lutfih and Quraish Shihab, and other ustaz from the Al-Huda Islamic Boarding School.

It shows that the freedom of information streams via the internet allows knowledge and understanding of Islamic religion to be accessed very quickly. The importance of information and the availability of facilities can provide simplicity, and suspected to be one of the factors that create dependency among its users. The increase of human dependence on media made it increasingly important due to its practicality, speed, and limitless of information that can be found.

\footnotetext{
13 Hatta. Muhammad, "Media Sosial sebagai Sumber Keberagamaan Alternatif Remaja dalam Fenomena Cyberreligion." Dakwah 22, no. 1 (2018), 7.

${ }^{14}$ Annazilli. M.Haqqi, "Relasi antara Agama dan Media Baru," 29.

15 Kartini. Retno, dkk. Wacana Ekstrimisme Keagamaan di Media Online, Pertama. (Jakarta: Puslitbang Lektur Khazanah Keagamaan dan Manajemen Organisasi, 2018), 5.
} 


\section{Online Media; Establishment of Religious Understanding and Practices of Madrasah Aliyah Students in Gorontalo}

It's beyond doubt that online media has a significant influence in shaping students' understanding and religious attitudes. In this study, we found a portion of experiences from Madrasah Aliyah students who were the active users of online media with time they spent between 2 and 10 hours every day, and they even considered social media as crucial tools that provided them circulation of information so quickly. According to them, the likelihood to use online media is based on three different reasons; (1) looking for information in the form of Islamic studies, (2) as entertainment media, and (3) as a means of communication. Likewise, the themes that student accessed are very miscellaneous among others, for example, Islamic law, fiqh, muamalah, hadith, the basics of Islam teachings for adolescents, tolerance, nationality, hijab, aurat, association in Islam, Muslim women, hijrah, hijab, khimar, Islamic view of dating, differences opinion on the veil, biographies of the Prophet's sahabah, khilafah, in addition to accessing the religious learning.

Online media as an alternative source of obtaining religious knowledge, even doesn't rule out the possibility of shaping the understanding and religious attitudes of students of Madrasah Aliyah in Gorontalo, including their views on the state, social relations, culture, or traditions that are still practiced in society.

In the context of the Khilafah, the students' understanding was quite moderate. According to them, every religion was in order for benefit of the people (maslahat), as well as to reduce disadvantage (mudharat). Seeing Indonesia as a multicultural country, the formation of the Khilafah directly without the process of maturing people's ideology will actually lead to frictions and conflicts. Indonesia is not an Islamic country; it consists of heterogeneous religions. Pancasila as the ideology of Indonesia, already inscribed on its first principle, believing in one Almighty God, emphasizes that there is not only one religion that is recognized in this state. In addition, Islam has also taught its followers how to protect the weak, but that doesn't mean to recognize their religion as true religions. Indonesia is a multicultural country and it will be better for the people to live in harmony under the Republic of Indonesia.

Regarding the tolerance in Indonesia, it is actually compelling but there are still a number of groups that are trying to divide the ummah, even within the Islamic group itself. In terms of relations with non-Muslims, it is still necessary to build good communication, if they also have an attitude of tolerance, then they do not have to be shunned. Islam has taught as Rasulullah when he was in Medina to live with people of different beliefs, thus giving birth to the Hudaibiyah agreement, a pledge to obey the Prophet. Likewise, how Umar bin Khattab taught tolerance when he conquered Palestine, next to the Aqsa mosque there was a church but he allowed it to stand beside the mosque. Building communication and relationships with people who are different or tolerate is an obligation, mutual respect is the essence of Islam as a religion of peace.

In terms of tolerance or respect for a difference, the students have understood and practiced it well, however, in a particular issue, it still appears a sense of reluctance due to issues related to their beliefs, for example, wishing someone a Merry Christmas. In their perspective, saying Merry Christmas has never been done by the salaf group, therefore people who do that considered as tasabbuh, it poses a big sin and could jeopardize someone's faith and expel it from their religion. According to their approach, when someone says Merry Christmas, it's equivalent on agreeing their beliefs and believe that Jesus is God. Giving congratulations is also not allowed because it has been clearly stated in QS Al-Kafirun. Despite disagreement of wishing Merry Christmas, they were not hesitant to attend the Christmas celebration when they were invited, as a token of appreciation for Christian people.

Furthermore, regarding issues of culture or tradition that are still widely practiced in society, students unanimously agree that as long as the tradition doesn't contradict Islamic values, it's still doable to be celebrated, in contrary, if the act contains shirk or heresy, then muslim are expected to leave the traditions. In Gorontalo, there's a tribe of indigenous people 
who still intensively carry out various rituals or traditions in the life cycle, so that students respond it differently.

Traditions/customs, as long as they don't contain shirk, but traditions on behalf of local wisdom in Islam are prohibited, but in the context of a state it appears. Traditions may be carried out as long as they do not violate religious norms, and if the source is clear as exemplified by the Prophet, then it can be followed, but if the source is not clear then it must be rejected. Even now there has been a modification by including customary values in it. For example, marriage, the tradition of cutting hair (akikah), it's adopted from Islamic values so it doesn't consider as problems. Likewise, the traditions/customs in Gorontalo, for example, doa arwah (prayer for deceased people), tahlilan, are still being carried out.

As for the mawlid tradition, barzanji is an act that has never been exemplified by the prophet or his friends or the salaf, so there is no need to prove the love for the prophet with such things, it's enough to follow what is ordered and leave the prohibitions, even his friends who are very close to the Prophet also didn't celebrate it. In this case, it appears that the different views wre expressed by students regarding the implementation of mawlid or barzanji. In the lifetime of Prophet Muhammad, such things never been done by himself and his companions, but it once when celebrated by Prophet's uncle to express his joy over birth of the Prophet, he invited the Quraish people with great joy and happiness, then served food to be enjoyed with people. Likewise, in the implementation of the barzanji, as a literary expression of the prophet's syirah, then it is permissible to do so, as long as the barzanji is not done excessively. It is not an obligation that must be done at every celebration, so it shouldn't be said as an act of heresy or forbidden thing.

An interesting thing is also found related to nationalism, regarding to the Republic of Indonesia and the phenomenon of flag salute, some students prohibit it. But in this case, students have unsolid opinion in their response. A student who is also active in the salafi group, has a different view, he said that the flag salute couldn't be considered as act of worship, but is a tribute to the services of heroes who have fought for the country with full sincerity. Despite some students believe that flag salute should be avoided because it denotes worship of something other than God, but in practice they still attend the flag ceremony at school.

The freedom to access religious content shows that the religious dimension in social media is characteristic of a broad cultural style, which is attached to the da'wah space that can be accessed by audiences. Understanding religion and conveying it to the public via the internet, is a sign that religious communication is slowly reducing the previously known religious values. The presence of the internet as a new media has the advantage of building very high information and connectivity and enabling more comprehensive communication. ${ }^{16}$

Decoding and encoding are ways of explaining that the same message can be sent and interpreted in more than one way. This method focuses more on the idea that the audience sometimes translates messages in ways that are incompatible with the original means of the messages results in different meanings. A message that is sent or delivered will affect the audience. Stuart Hall identified three audience categories that have undergone the encoding/decoding process of a message. ${ }^{17}$

Decoding is an activity of translating physical messages into a form that has meaning for the recipient. Stuart Hall said that the audience decodes the media message through three possible positions: first, the audience's hegemonic position, where the audience receives the message conveyed by the media. The media convey messages using the dominant cultural code in society. Second, the negotiating position is stated by Stuart Hall, where the audience assimilates the leading ideology in general but opposes its application in a specific case. It means that the audience accepts the ideology in general, but they applied the filter to its contents,

\footnotetext{
16 Rubawati. Efa, "Berita Online sebagai Instrumen Dakwah antara Profetik dan Provokatof," Tasamuh: Studi Islam 10, no. 1 (2018): 2.

17 Zohrah. Fatimah, "Pemaksanaan Khalayak terhadap Informasi Kasus Penodaan Agama oleh Basuki Tjahja Purnama di Media Sosial.”, 4-5.
} 
which in practices, it must adapt to local customs/culture, and third is the position of opposition, this model is the last way for the public to decode media messages, namely when the audience changes or changes the message or the code provided by the media with an alternative code or message. ${ }^{18}$

Thus, online media is a means of preaching, where religious messages are conveyed according to the dominant culture such as behavior, ritual values, and social habits in society. In this context, if it's related to decoding, religious content conveyed by preachers or Ustaz/ustadzah through social media has its own magnet, students seem to accept as an integrated message, where religious content is deemed appropriate and per the conditions and their current needs. However, in terms of understanding and practice, they still filter the content they access before it is conveyed to other audiences, so as not to cause pros and cons. First, do a search for the source of the law either through religious reading or asking people who are thought to know better.

Symptoms of reliance on social media for accessing information, including religious content, also affected students of Madasah Aliyah in Gorontalo. An intriguing question is what's wrong with the "ngaji online" model that afflicts some students of Madrasah Aliyah in Gorontalo? Professor Adam, director of research at the School of Social Sciences and Psychology, University of Western Sydney also feels uneasy about the phenomenon of cyberreligion, where previous understanding has shifted, which is certainly not without reason. In the postmodern era today, like it or not, religion has become part of the culture of consumerism. Nowadays religion is no longer understood as it used to be, religious rituals have become something that no longer needs to be questioned, opposed or practiced incompatible with the norm. This industrial and modern world today forces people to enter an instant, practical, and fast way, including the religious life of the community. Likewise, "ngaji online", a religion on the internet that is widely followed by the Muslim millennial generation. Tawsiyah can be easily accessed via smartphone and the topic can be easily selected according to their wishes. With online media, young people can be connected in accessing excessive religious information. ${ }^{19}$

The religious phenomenon that has been shown by some Islamic school students in Gorontalo has at least been influenced by online media. Phenomenon of "ngaji online" shows several symptoms that lead to the formation of religious understanding and practices that tend to be "exclusive", even leading to a conservative understanding, including forbidding music, not being willing to be photographed, doing mawlid, barzanji, reluctance to be led by someone with different religion, wish merry Christmas, and celebrate valentine's day. It is undeniable that online media has significant influence on them, in addition to their activeness in participating in religious studies at school (Rohis) and outside of school and the references they read.

\section{Aligning the Religious Understanding of Students at Madrasah Aliyah}

Online media inevitably influence in shaping the religious understanding of Islamic school students. However, it is not the only factor that lead them it that behavior. In responding to the religious understanding of students at Madrasah Aliyah, in order to avoid an "exclusive" understanding, there are several efforts were made by the school to harmonizing their perspective.

\section{a. School Policy}

To anticipate the exclusive attitude among students, especially the dependence of students in accessing religious content through online media, one of the policies enforced in schools is to restrict the use of mobile phones. The use of smartphones for students only allowed to access learning or assignments that have been given by each teacher. Apart from restricting the use of phones, especially in MAN 1 Gorontalo, the board of schools also controls student extracurricular

\footnotetext{
18 Susanti.Billy, Analisis Resepsi terhadap Rasisme Keberagamaan Remaja dan Solusinya Melalui Pendidikan Agama Islam (Surakarta, 2014).4.

${ }_{19}$ Hatta. Muhammad, "Media Sosial sebagai Sumber Keberagamaan Alternatif Remaja dalam Fenomena Cyberreligion.”. Dakwah 22, no. 1 (2018): 12.
} 
activities including ROHIS. The ROHIS mentor also monitors their activities, so that there is no excessive concern about religious understanding or behavior. Also, at each ceremony held in school, the school convey their messages by inserting the values of religious moderation.

It's different from the three remaining schools, MA Al-Yusrah, MA Al-Khaeart, and MAS AlHuda, which do not have extracurricular activities (ROHIS). In this case, MA Al-Huda's Student Deputy Chief stated that indeed in MAS Al-Huda and Al-Khaerat, there was no ROHIS, because there was quite a lot of religious learning. In addition to getting religious learning based on the curriculum of the Ministry of Religion, it is also equipped with Islamic boarding school learning, except that the recitation of the book is only given to students who are in boarding school. In addition, there are also studies given by teachers and mentors at schools, always reinforcing students related to Aswaja (NU).

\section{b. Strengthening the Capacity of Understanding Religious Moderation for Teachers and Students}

Responding to the religious understanding of students in Madrasah Aliyah today, who are quite religious, both affiliated with mainstream religious groups such as NU and Muhammadiyah, as well as those affiliated with Salafist ideology. Therefore, the school intensely in instilling moderate religious values in both teachers and students. Even before the existence of the religious moderation program, the school had long followed this principle. Madrasahs are not only found by one community but also from various parts of the region including those who come from outside Gorontalo with various religious, cultural, and cultural affiliations that they under. Therefore, the school always monitors, especially on religious studies involving outsiders, and does not educate students on certain understandings (abstracted interviews).

The role of the school in harmonizing a "strange" religious understanding is to explaining the ideology according to the syllabus and curriculum, delivery must be more in-depth, the teachers first have to understand the problems that are currently developing. Apart from that, intensifying extracurricular activities, as well as when getting information from the media, one has to practice, examine more deeply what the basis is. Also, there is enough closeness between students and teachers, so that they are not awkward, even make friends on social media, so they can monitor children's posts if something is strange (interview, Yusuf Bagu, March 2020, in Gorontalo).

The aforementioned statement shows that the school does not make payments, contrary, it has tried as early as possible and intensely in providing direction, guidance, and guidance to students, so that religious understanding and practice do not lead to "exclusive" and "conservative" understandings.

\section{E. Conclusions}

The use of online media among school-age adolescents has become a necessity for every student, in addition to completing school assignments, also to access various information instantly. Including MA students, this is indicated by the intensity of time used above 4 to 10 hours/day, with various kinds of sites as well as FB, WA, IG, Google, Twitter, and Youtube. They are good at using them to surf in cyberspace without limitations, accessing various information including religious content.

The tendency for religious content to be accessed both through pages/sites and YouTube channels is almost uniform, in this case, mostly they used it for finding the preachers they interested in. However, some students, especially IPPNU students, have quite a variety of access to religious posts and lectures that are served through online media. Online media has influenced students' religious understanding, attitudes, and practices in MA, it also shows the existence of "exclusive" symptoms, and "exclusive" militancy, even leading to conservative religious understanding militancy, such as forbidding music, not taking pictures, mawlid Nabi, barzanji, no 
willing to be led by leaders of different religions, wish someone merry Christmas, and as well as celebrate Valentine's Day.

The school's efforts to harmonize understandings that are considered as "exclusive" and "conservative" attitudes, as follows: institutional policies, strengthening the understanding of religious moderation for both teachers and students, being selective in accepting murabbi who will provide religious studies on extra-curricular activities of ROHIS, build communication with students, especially in social media, and make friends in social media in order to facilitate and control of each student's posts.

\section{References}

Ahmadin. Metode Penelitian Sosial. Pertama. Jakarta: Rayhan Intermedia, 2013.

Annazilli. M.Haqqi. “Relasi antara Agama dan Media Baru.” Syi'ar 18, no. 2 (2018).

Eddy, Saputra. "Dampak Media Sosial terhadap Sikap Keberagamaan Remaja dan Solusinya Melalui Pendidikan Agama Islam." Sosial E-Kons 8, no. 2 (2016).

Eriyanto. Analisis Wacana Pengantar Analisis Teks Media. Pertama. Jogyakarta: LKiS, 2005.

Hatta. Muhammad. "Media Sosial sebagai Sumber Keberagamaan Alternatif Remaja dalam Fenomena Cyberreligion." Dakwah 22, no. 1 (2018).

Kartini. Retno, dkk. Wacana Ekstrimisme Keagamaan di Media Online. Pertama. Jakarta: Puslitbang Lektur Khazanah Keagamaan dan Manajemen Organisasi, 2018.

McQuail. Dennis. Teori Komunikasi Massa Mc.Quail. Enam. Jakarta: Salemba Humanika, 2011.

Nurfitrih Aldila Dyas dan Mulawarman. "Perilaku Pengguna Media Sosial Beserta Implikasinya Ditinjau dari Perspektif Psikologi Sosial Terapan." Buletin Psikologi 25, no. 1 (2017).

Paisal, dkk. Media Online dan Pembentukan Pemahaman Keagamaan Siswa Di MA Pada Kawasan Timur Indonesia. Makassar, 2020.

Rubawati. Efa. "Berita Online sebagai Instrumen Dakwah antara Profetik dan Provokatof." Tasamuh: Studi Islam 10, no. 1 (2018).

Susanti.Billy. Analisis Resepsi terhadap RasismeKeberagamaan Remaja dan Solusinya Melalui Pendidikan Agama Islam. Surakarta, 2014.

Syamsurijal. Media Online dan Pembentukan Pemahaman Keagamaan Siswa: Kasus Peserta Didik di MA Parepare dan Makassar, 2020.

Zohrah. Fatimah. "Pemaksanaan Khalayak terhadap Informasi Kasus Penodaan Agama oleh Basuki Tjahja Purnama di Media Sosial.” Universitas Diponegoro Semarang, 2017. 